Article

\title{
Non-Deep Simple Morphophysiological Dormancy and Germination Characteristics of Gentiana triflora var. japonica (Kusn.) H. Hara (Gentianaceae), a Rare Perennial Herb in Korea
}

\author{
Hyeon-Min Kim ${ }^{1}$, Jun-Hyeok Kim ${ }^{1}$, Da-Hyun Lee ${ }^{1}$, Young-Ho Jung ${ }^{1}$, Chung-Youl Park ${ }^{1}$, Mi-Hyun Lee ${ }^{1}$, \\ Kyeong-Min Kim ${ }^{1}$, Jae-Hyeon Lee ${ }^{2}$ and Chae-Sun $\mathrm{Na}^{1, *(D)}$
}

1 Wild Plant Seed Research Division, Baekdudaegan National Arboretum, Bonghwa 36209, Korea; khm0766@koagi.or.kr (H.-M.K.); kjh9859@koagi.or.kr (J.-H.K.); dahyun0519@koagi.or.kr (D.-H.L.); jyh5250@koagi.or.kr (Y.-H.J.); doonas@koagi.or.kr (C.-Y.P.); hyun3176@koagi.or.kr (M.-H.L.); katty1502@koagi.or.kr (K.-M.K.)

2 Forest Bioresource Investigation Team, Baekdudaegan National Arboretum, Bonghwa 36209, Korea; ecojay@koagi.or.kr

* Correspondence: chaesun.na@koagi.or.kr; Tel.: +82-054-679-2769

Citation: Kim, H.-M.; Kim, J.-H.; Lee, D.-H.; Jung, Y.-H.; Park, C.-Y.; Lee, M.-H.; Kim, K.-M.; Lee, J.-H.; Na, C.-S. Non-Deep Simple

Morphophysiological Dormancy and Germination Characteristics of Gentiana triflora var. japonica (Kusn.) H. Hara (Gentianaceae), a Rare Perennial Herb in Korea. Plants 2021, 10, 1979. https://doi.org/10.3390/ plants10101979

Academic Editor: Roberta Masin

Received: 3 August 2021

Accepted: 17 September 2021

Published: 22 September 2021

Publisher's Note: MDPI stays neutral with regard to jurisdictional claims in published maps and institutional affiliations.

Copyright: (c) 2021 by the authors. Licensee MDPI, Basel, Switzerland. This article is an open access article distributed under the terms and conditions of the Creative Commons Attribution (CC BY) license (https:/ / creativecommons.org/licenses/by/ $4.0 /)$.

\begin{abstract}
This study investigated the kind of seed dormancy and seed germination of Gentiana triflora var. japonica (Kusn.) H. Hara for developing a seed propagation method. The seeds were collected in October 2020 from plants at Mt. Sobaeksan, Korea. In a water imbibition experiment, seed weights increased by $>101.9 \%$ of their initial masses over $12 \mathrm{~h}$. Effects of incubation temperature $(5,15,20,25$, $15 / 6$, or $\left.25 / 15^{\circ} \mathrm{C}\right)$, cold stratification period $\left(5^{\circ} \mathrm{C} ; 0,4,8\right.$, or 12 weeks), and gibberellic acid $\left(\mathrm{GA}_{3} ; 0,10\right.$, 100 , or $\left.1000 \mathrm{mg} \cdot \mathrm{L}^{-1}\right)$ and potassium nitrate treatment $\left(\mathrm{KNO}_{3} ; 0,1000,2000\right.$, or $\left.4000 \mathrm{mg} \cdot \mathrm{L}^{-1}\right)$ on seed germination were investigated to characterize seed dormancy. These seeds exhibited underdeveloped embryos during seed dispersal. The seeds failed to reach the final germination of $15.0 \%$ after treatment at $5,15,20,25,15 / 6$, or $25 / 15^{\circ} \mathrm{C}$. After cold stratification for 8 weeks, the germination increased dramatically by $>90.0 \%$ compared to that at 0 weeks. After the $\mathrm{GA}_{3}$ treatment, the germination reached $>80.0 \%$ within 5 days. The final germination was $90.0 \%$ in the $100 \mathrm{mg} \cdot \mathrm{L}^{-1} \mathrm{GA}_{3}$ treatment group. However, the $\mathrm{KNO}_{3}$ treatment had no effect on seed germination. Therefore, the G. triflora var. japonica seeds exhibited non-deep simple morphophysiological dormancy.
\end{abstract}

Keywords: cold stratification; gibberellic acid; rare plant; seed propagation; underdeveloped embryos

\section{Introduction}

The success of seed germination is the most important feature for establishing and propagating plant seedlings in nature [1-4]. Several mechanisms control seed germination, including temperature, moisture, humidity, and light, among which seed dormancy is the most important [5]. Although seed dormancy is a critical plant trait from the ecological and conservation perspectives, understanding how to overcome seed dormancy can enable the use of wild plant species that are potentially valuable to the agricultural and horticultural industries $[6,7]$. Recently, consumers have become increasingly interested in medicinal plants and/or highvalue crops using natural substances in the pharmaceutical, animal feed, human food, and cosmetics industries. In addition, plants, especially those with medicinal components, play an essential role in improving health care [8]. Numerous studies on the germination characteristics, seedlings, plant culture, and secondary metabolites of commonly grown potential medicinal plants, such as Allium hirtifolium Boiss., Ocimum basilicum L., Crepidiastrum denticulatum, Salvia plebeian R. Br., Mesembryanthemum crystallinum L., and Oenanthe stolonifera have been conducted [9-14]. Currently, the number of wild plants is decreasing due to climate change and the destruction of native habitats, and basic data on seed germination characteristics are required for forest restoration and conservation of these native plants. However, although various conservation and taxonomic studies on wild plants are being conducted, 
studies on mass propagation to industrialize these plants are insufficient. Therefore, it is necessary to not only examine seed germination to establish mass production, but to also investigate the seed dormancy type of wild plants to utilize their medicinal resources and restore forests.

Seed dormancy is classified by the developmental status of the embryo, water absorption capacity, and interrelationships of phytohormones in seeds. Baskin and Baskin [15] reported that seed dormancy is divided into five categories: physiological dormancy (PD), morphological dormancy (MD), morphophysiological dormancy (MPD), physical dormancy (PY), and combinational dormancy (PY + PD). Generally, the Gentianaceae family has been reported to exhibit PD or MPD [16]. Similarly, the seeds of the genus Gentiana display non-deep PD and intermediate-complex MPD [17-19]. Even among seeds of the same genus, the dormancy class is species-specific. Dormancy must be released in seeds with PD and MPD, and this requires seeds to be pretreated using cold $\left(0-10^{\circ} \mathrm{C}\right)$ and /or warm $\left(\geq 15^{\circ} \mathrm{C}\right)$ stratification, gibberellins (GAs), and ripening in dry storage [20]. Furthermore, MPD is classified into eight levels, and systematic studies are required to investigate the exact dormancy of seeds. In particular, gibberellic acid $\left(\mathrm{GA}_{3}\right)$ is commonly used to break dormancy, enhance germination, promote embryo growth, and stimulate radicle emergence in many plant species [21-24]. In addition, $\mathrm{GA}_{3}$ is not only easy to apply to investigate seed dormancy release, but also does not require special equipment or facilities. $\mathrm{GA}_{3}$, however, does not enhance germination of all the species; in fact, germination may be suppressed depending on the method and/or concentration used. Similarly, cold and/or warm stratification are widely known to aid in releasing dormancy and promoting embryo growth of PD- or MPD-type seeds [20,25,26].

In Gentianaceae, the genus Gentiana includes approximately 360 species that are distributed worldwide, mainly in temperate, arctic, and alpine habitats of the northern hemisphere [27]. The genus Gentiana has been reported to include 16 taxa distributed throughout Korea; among them, G. triflora var. japonica (English name: East Asian clustered gentian, Korean name: Gwa-nam-pul) is a rare (least-concern, LC) perennial species in Korea [28]. Several taxonomic [29] and pharmacognostical studies [30] have been conducted on Gentiana plants in Korea. Therefore, it is necessary to investigate not only the in situ, but also the ex situ conservation. Studies have also identified that the Gentiana genus possesses the pharmacological ingredients gentiopicroside, gentiin, gentisin, gentiopicrin, and gentiotriose in its roots, and the plants are used as an Oriental medicine for anorexia, carditis, liver protection, cholangitis, and anticancer activity [31,32].

In this study, we investigated the response of G. triflora var. japonica seeds to various temperature conditions to improve seed germination. In addition, we examined G. triflora var. japonica seeds by studying the effects of cold stratification, $\mathrm{GA}_{3}$, and $\mathrm{KNO}_{3}$ on the dormancy release and seed germination characteristics under laboratory conditions and investigated a suitable germination protocol to confirm the feasibility of its practical application for the establishment of a mass production system.

\section{Results}

\subsection{Water Imbibition Test}

Water absorption by the G. triflora var. japonica seeds immediately increased their weight by $63.1 \pm 15.8 \%$ compared to the initial mass after $3 \mathrm{~h}$. In addition, $72 \mathrm{~h}$ after the immersion in distilled water, the seeds reached the saturated state at $118.8 \pm 15.4 \%$ (Figure 1).

\subsection{Seed Morphology and Embryo Growth}

The light-blue flowers of G. triflora var. japonica open in July and August in Korea, and one to five flowers occur at the upper leaf axil or at the tip (Figure 2A). In the case of fruits, the capsule types were composed of multi-core skin (Figure 2B). The seeds had caudal appendages at the time of dispersal, and the length and width of the seeds was less than $1 \mathrm{~mm}$ (Figure 2C). The seeds of G. triflora var. japonica had underdeveloped 
embryos at dispersal (Figure 2D). However, seed embryos were fully developed just before germination, and the radicle was protruded (Figure 2E,F). The embryo/seed (E:S) ratios at dispersal and just before germination were $0.32 \pm 0.04$ and $0.58 \pm 0.03 \mathrm{~mm}$, respectively (Figure 3).

\subsection{Temperature Regime Treatments}

Figure 4 shows that the cumulative germination was influenced by temperature treatments used to release dormancy and determine the optimal temperature conditions for the germination of G. triflora var. japonica seeds. The average germination of all the temperature treatment groups during the 10-week incubation period was less than $12.0 \%$. In the constant temperature groups at 5,15 , and $20^{\circ} \mathrm{C}$, the germination was remarkably lower than $5.0 \%$ over the 10 weeks. When the seeds were incubated at the alternating temperatures of $15 / 6^{\circ} \mathrm{C}$, the germination was $11.0 \pm 3.0 \%$ for 7 weeks.

\subsection{Cold Stratification Period}

The cumulative germination of the G. triflora var. japonica seeds, as influenced by the cold stratification period $(0,4,8$, or 12 weeks), is shown in Figure 5 . The control seeds without cold stratification ( 0 weeks) did not germinate within 16 weeks. However, $\geq 78.0 \%$ of the seeds from the other treatment groups germinated after cold stratification for 4, 8 , or 12 weeks. In particular, the germination was greater than $90.0 \% \pm 1.9 \%$ at 16 weeks in the group with cold stratification for 8 weeks, which was significantly higher than that observed for the other treatment groups.

\subsection{Promotion of Germination by $\mathrm{GA}_{3}$ and $\mathrm{KNO}_{3}$}

Germination of the G. triflora var. japonica seeds was improved following pretreatment with a $\mathrm{GA}_{3}$ solution (Figure 6A). The final germination of the seeds pretreated with 100 and $1000 \mathrm{mg} \cdot \mathrm{L}^{-1} \mathrm{GA}_{3}$ was $90.0 \pm 2.0 \%$ and $84.0 \pm 4.3 \%$, respectively, with the mean germination time (MGT) of $9.3 \pm 0.6$ and $7.6 \pm 0.7$ days, respectively, which was significantly higher than the MGT in case of the other treatments (Figure 6B). Furthermore, the germination energy at 0-7 days was significantly increased with 100 and $1000 \mathrm{mg} \cdot \mathrm{L}^{-1} \mathrm{GA}_{3}$ (Figure 6C). However, germination was not significantly affected by the $\mathrm{KNO}_{3}$ concentration, indicating that osmotic priming by applying $\mathrm{KNO}_{3}$ was ineffective. In all the treatment groups, the cumulative germination did not exceed $10.0 \%$ until 10 weeks (Figure 7 ).

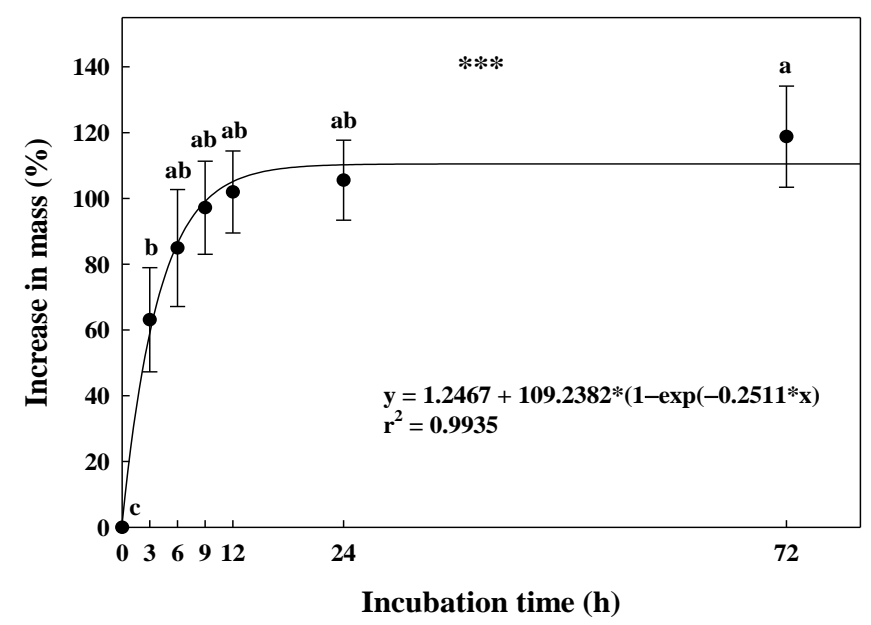

Figure 1. Changes in the mass of the Gentiana triflora var. japonica (Kusn.) H. Hara seeds during water incubation. The seeds were incubated at room temperature (approximately $25 \pm 2{ }^{\circ} \mathrm{C}$ ) on filter paper moistened with distilled water for $24 \mathrm{~h}$. Vertical bars represent the standard deviation from the mean $(n=4)$. Different letters in the same column indicate significant differences based on Tukey's multiple range test $(p \leq 0.05)$. ${ }^{* *}$ Significant at $p \leq 0.001$. 

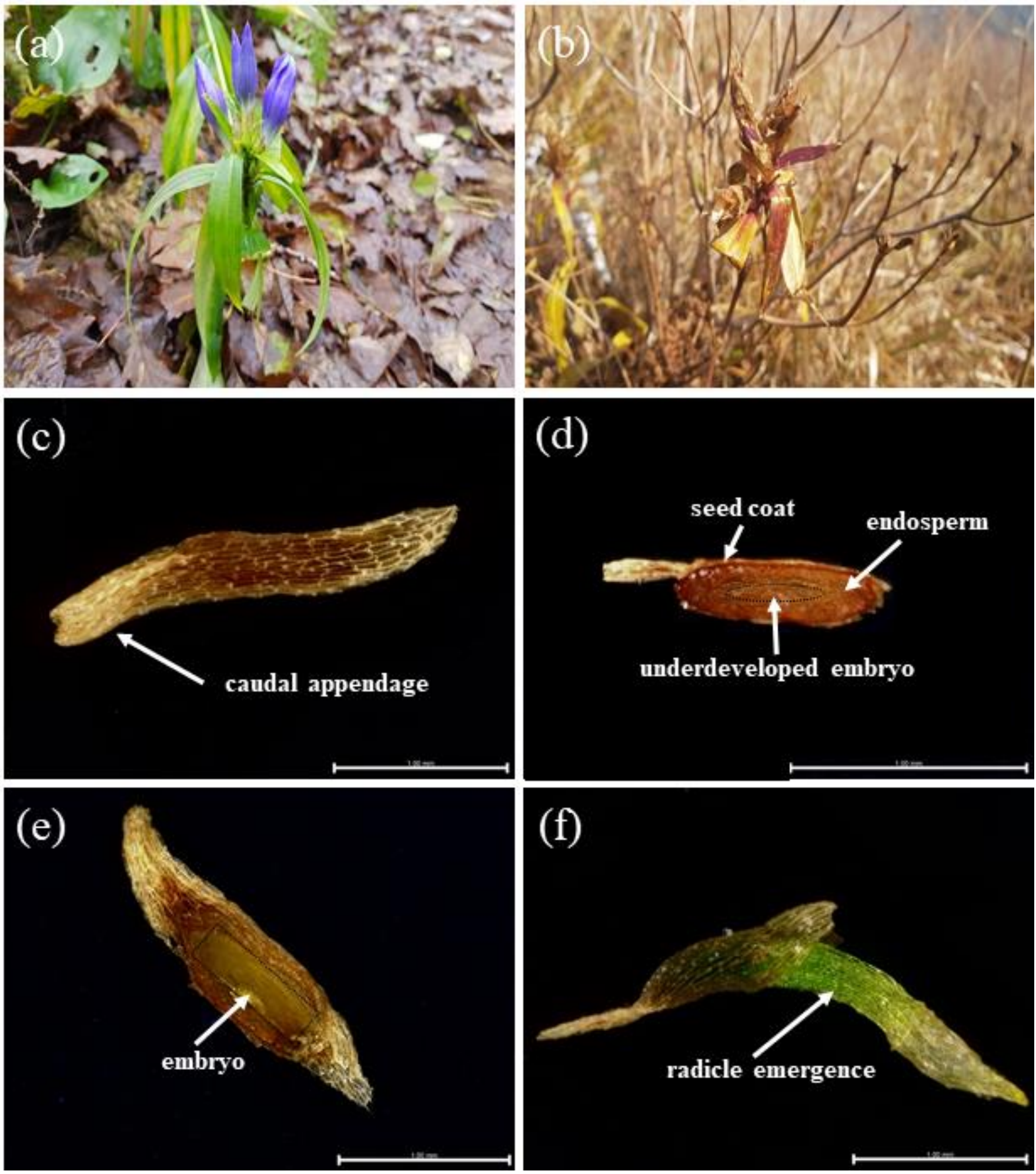

Figure 2. Flowers (a), capsules (b), seed (c), underdeveloped embryo at dispersal (d), fully developed embryo just before germination (e), and radicle emergence (f) of Gentiana triflora var. japonica (Kusn.) H. Hara (scale bar $=1 \mathrm{~mm}$ ). 


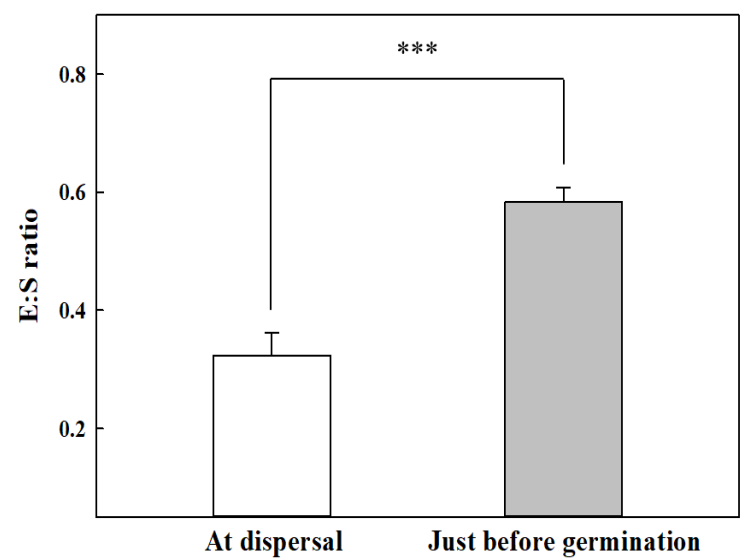

Figure 3. Embryo/seed (E:S) ratios in the seeds of Gentiana triflora var. japonica (Kusn.) H. Hara at seed dispersal and just before germination. Vertical bars represent the standard deviation from the mean $(n=10)$. Each E:S ratio at dispersal and just before germination was compared using a paired $t$-test. ${ }^{* * *}$ Significant at $p \leq 0.001$.

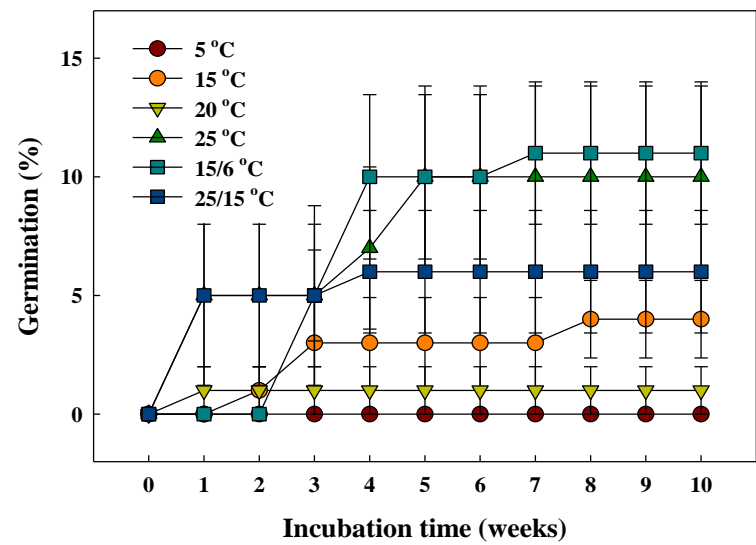

Figure 4. Cumulative germination of the Gentiana triflora var. japonica (Kusn.) H. Hara seeds in six temperature regimes $\left(5,15,20,25,15 / 6\right.$, and $\left.25 / 15^{\circ} \mathrm{C}\right)$. Vertical bars represent the standard deviation from the mean $(n=4)$.

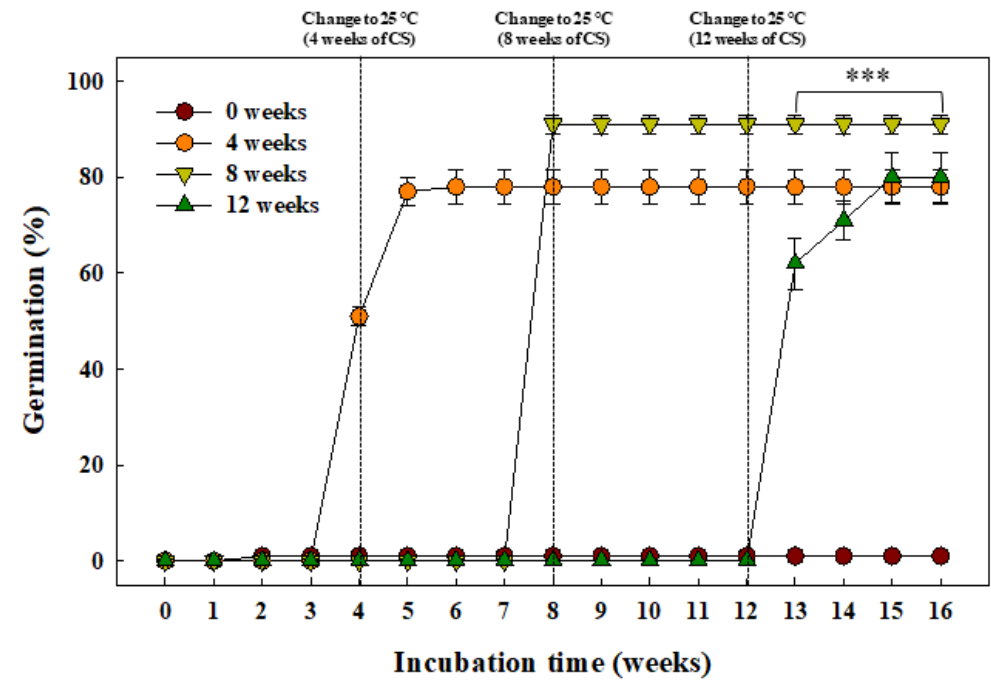

Figure 5. Cumulative germination of the Gentiana triflora var. japonica (Kusn.) H. Hara seeds treated with cold stratification $(0,4,8$, or 12 weeks). Vertical bars represent the standard deviation from the mean $(n=4){ }^{* * *}$ Significant at $p \leq 0.001$. 


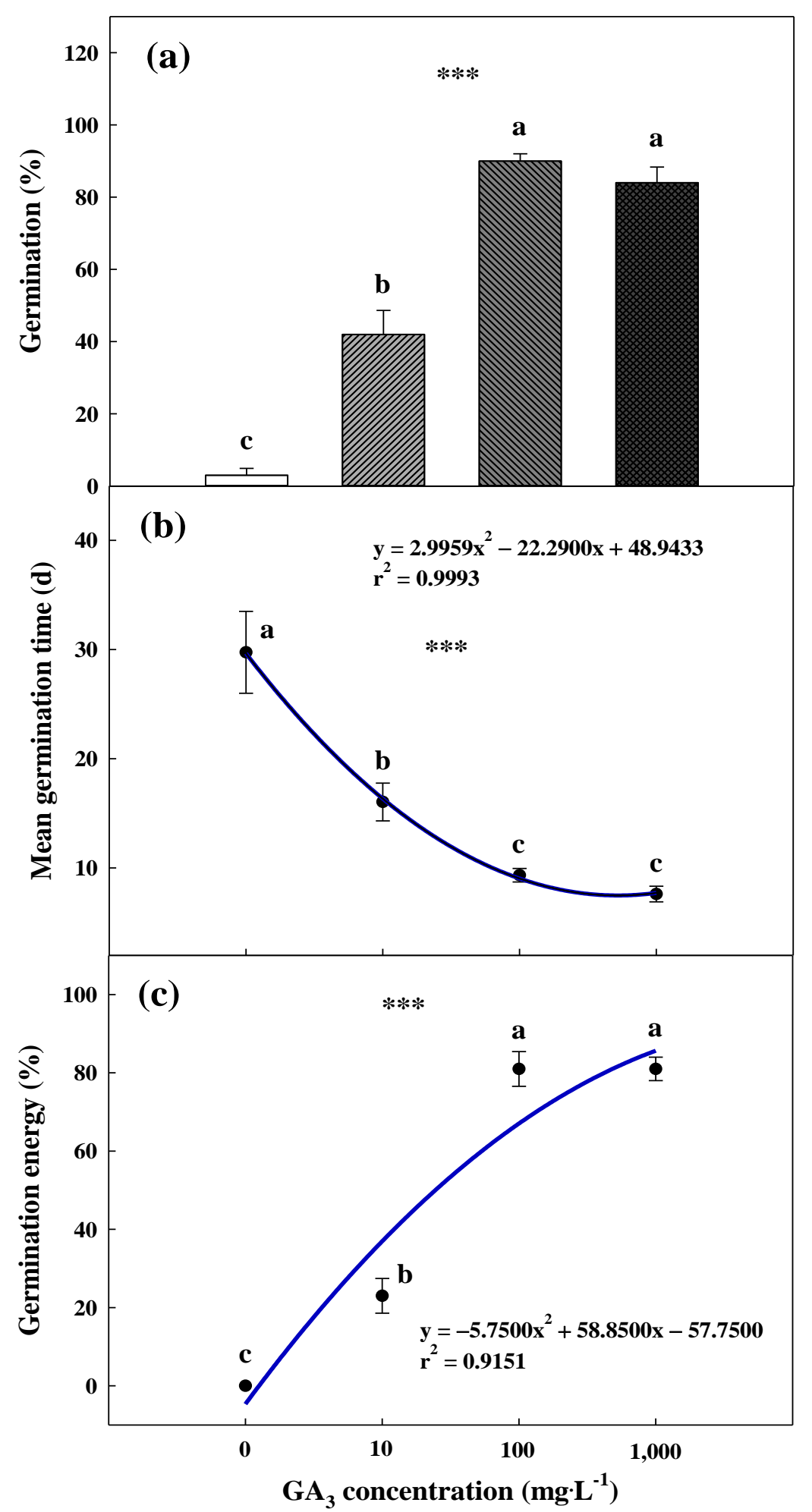

Figure 6. Germination percentage (a) and the mean germination time (b) of the Gentiana triflora var. japonica (Kusn.) H. Hara seeds pretreated with $\mathrm{GA}_{3}\left(0,10,100\right.$, or $1000 \mathrm{mg} \cdot \mathrm{L}^{-1}$ ) for 30 days. Germination energy (c) of the Gentiana triflora var. japonica (Kusn.) H. Hara seeds pretreated with $\mathrm{GA}_{3}\left(0,10,100\right.$, or $\left.1000 \mathrm{mg} \cdot \mathrm{L}^{-1}\right)$ for 7 days. Vertical bars represent the standard deviation from the mean $(n=4)$. Different letters in the same column indicate significant differences based on Tukey's multiple range test $(p \leq 0.05)$. ${ }^{* *}$ Significant at $p \leq 0.001$. 


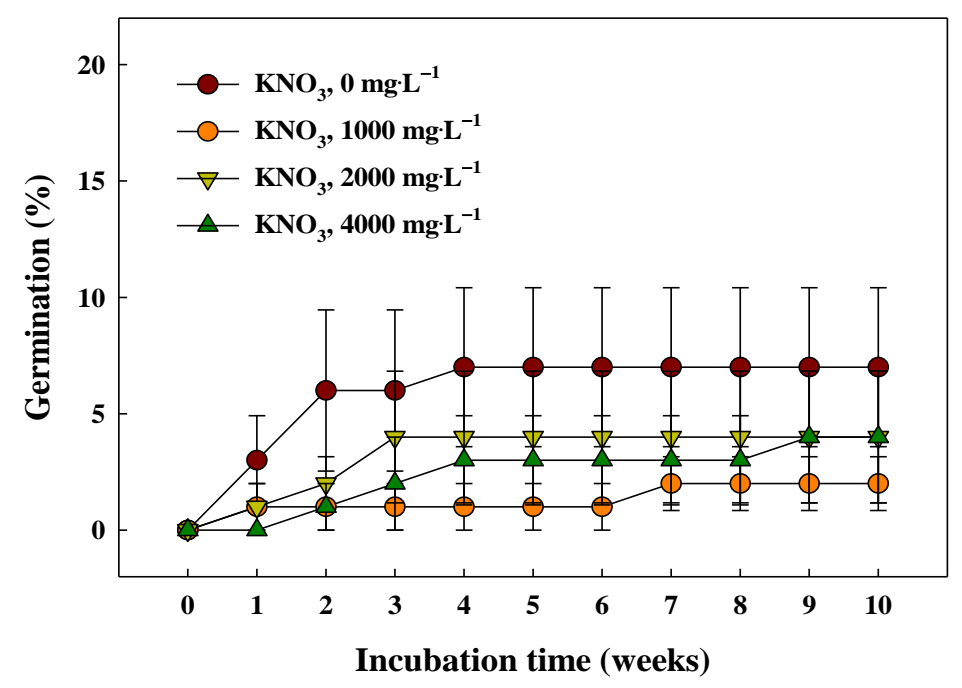

Figure 7. Cumulative germination of the Gentiana triflora var. japonica (Kusn.) H. Hara seeds pretreated with $\mathrm{KNO}_{3}\left(0,1000,2000\right.$, or $\left.4000 \mathrm{mg} \cdot \mathrm{L}^{-1}\right)$. Vertical bars represent the standard deviation from the mean $(n=4)$.

\section{Discussion}

\subsection{Water Imbibition Test}

Deficient water imbibition by intact seeds due to the seed coat or pericarp is a characteristic feature of PY dormancy [3]. From the ecological point of view, PY dormancy of seeds with a thick coat or pericarp can be a strategy to adapt to an unfavorable environment and germinate at an appropriate time for the plant life cycle [33]. Seeds with PY dormancy can release dormancy and germinate through various mechanical or chemical treatments that damage the seed coat or pericarp, such as dipping in boiling water, dry heating, and treating with sulfuric acid [16,34]. If the water absorption rate is less than $20.0 \%$ of the initial seed weight after $12 \mathrm{~h}$ of incubation under laboratory conditions, then the seed is classified as water-impermeable [35]. In this study, the seed mass increased by more than $100.0 \%$ after $12 \mathrm{~h}$ of immersion in distilled water (Figure 1). Consequently, the seeds of G. triflora var. japonica imbibed readily, suggesting that the species does not exhibit PY dormancy.

\subsection{Seed Morphology, Embryo Growth, and Temperature Regime Treatments}

The seed embryos of G. triflora var. japonica were underdeveloped at the time of dispersal and significantly increased in length just before germination (Figures 2B and 3). According to Vandelook et al. [36], seed size and embryo length differ even within the same species, and the E:S ratio clearly represents the relative size of the embryos to the length of the seed. If the E:S ratio is $>0.5$, the embryo morphology is considered to be fully developed linear [37]. Seed dormancy with an undifferentiated or underdeveloped embryo can be classified as MD or MPD, which requires sufficient time for embryo development $[3,38]$. Generally, an underdeveloped embryo requires time to grow to the critical length for radicle protrusion, and Baskin and Baskin [20] reported that in seeds with MD dormancy, embryo development and germination occur within approximately 30 days under the optimal environmental conditions. The optimal germination temperature for each plant differs and is highly associated with the native habitat. Wild plant seeds native to temperate environments are known to have optimal germination temperatures between $24.0{ }^{\circ} \mathrm{C}$ and $30.0^{\circ} \mathrm{C}$ [39]. In this study, however, the seeds had MPD, as evidenced by poor germination of less than $12.0 \%$ by 10 weeks in the temperature regime groups (Figure 4 ), which is common in wild plant seeds during germination experiments. MPD is subdivided into eight levels according to the following distinctions: (i) the optimal temperature to break dormancy and promote germination, (ii) the optimal temperature during embryo development, and (iii) the application of GA to break seed dormancy [20,40]. Specifically, 
it is divided into simple and complex MPD types, which are necessary at relatively high temperatures $\left(\geq 15^{\circ} \mathrm{C}\right)$ and low temperatures $\left(0-10^{\circ} \mathrm{C}\right)$ at the time of embryo growth. Therefore, simple and complex types are further subdivided into deep, intermediate, and non-deep dormancy based on the level of PD dormancy [20,38]. Breaking of MPD and acceleration of germination commonly utilize exposure to alternating temperatures and/or application of GA solutions.

\subsection{Cold Stratification Period}

Dormancy breaking and germination were examined during cold stratification (Figure 5). Germination was significantly higher in the cold stratification group than in the control group, and it significantly improved during the 8-week period after cold stratification in the other treatment groups. Chilling requirements play an essential role in breaking dormancy in many species whose seeds have MPD [20]. In Arabidopsis, cold stratification requires the activation of GA biosynthesis in intact seeds for germination [41]. These phenomena break seed dormancy by antagonizing phytohormones inside the seeds and are highly related with the expression of many genes involved in seed germination. Cold stratification has been reported to improve seed germination in some New Zealand species of the Gentianaceae [42]. However, there are differences in the duration of cold stratification for breaking dormancy between species of the same genus or family plant groups. In this study, 4-8-week cold stratification periods were determined as the optimal duration for dormancy release and embryo development in G. triflora var. japonica seeds.

\subsection{Promoting Germination with $\mathrm{GA}_{3}$ and $\mathrm{KNO}_{3}$}

In a previous study, dormancy breaking and germination were improved by applying $\mathrm{GA}_{3}$ to Gentiana species; this has also been observed in numerous other plant species [22,43-46]. Similarly, in this study, the final germination was enhanced by the application of 100 and $1000 \mathrm{mg} \cdot \mathrm{L}^{-1}$ exogenous $\mathrm{GA}_{3}$ at $90.0 \pm 2.0 \%$ and $84.0 \pm 4.3 \%$, respectively (Figure 6A). Moreover, the MGT and germination energy (GE) values were improved following the application of $\mathrm{GA}_{3}$ at the concentrations of 100 and $1000 \mathrm{mg} \cdot \mathrm{L}^{-1}$ (Figure $6 \mathrm{~B}, \mathrm{C}$ ). In a previous study, $\mathrm{GA}_{3}$ application was more effective at $1000 \mathrm{mg} \cdot \mathrm{L}^{-1}$ than at 50 and $100 \mathrm{mg} \cdot \mathrm{L}^{-1}$ and positively affected the percentage and speed of germination in G. lutea L. var. aurantiaca seeds [43]. In addition, $250 \mathrm{mg} \cdot \mathrm{L}^{-1} \mathrm{GA}_{3}$ remarkably influenced the germination percentage compared to the results of 3-month cold stratification in G. lutea L. subsp. lutea seeds [22]. Endogenous phytohormones, especially GAs and abscisic acid (ABA), are known to regulate seed dormancy and germination. In PD-type dormancy, especially at non-deep levels, seed germination is regulated by quantitative changes and sensitivity to GAs and ABA $[16,20]$. Application of GAs promotes, the production of enzymes that hydrolyze cell walls after seed maturation, thereby accelerating radicle protrusion by decomposing the endosperm. In contrast, ABA suppresses GA synthesis and seed germination during dormancy release $[47,48]$. For this reason, the balance between GAs and $\mathrm{ABA}$ regulates the initiation, maintenance, and termination of seed dormancy.

Osmotic priming treatments (such as $\mathrm{KNO}_{3}, \mathrm{KCl}$, and $\mathrm{NH}_{4} \mathrm{NO}_{3}$ ) are large-scale pretreatments used for commercial propagation of plants to promote effective and uniform germination, and their use is expanding to wild plant seeds [49]. Among them, $\mathrm{KNO}_{3}$ is most often used as an osmotic regulator; specifically, nitrate is absorbed into the seeds and activates antioxidant enzymes and seed embryo metabolism [50]. In addition, the absorbed nitrate is used as a nutrient, which affects the regulation of GA and ABA involved in seed germination [51,52]. Millaku et al. [44] determined that the seeds of G. lutea L. had higher germination when pre-treated with a mixed solution of $1000 \mathrm{mg} \cdot \mathrm{L}^{-1} \mathrm{GA}_{3}$ and $0.1 \% \mathrm{KNO}_{3}$. Furthermore, the germination of wild plant seeds of Maesa japonica, Astilboides tabularis (Hemsl.) Engl., and Cicuta virosa L. was increased by the $\mathrm{KNO}_{3}$ priming treatment at high concentrations $[23,46,53]$. Therefore, germination and embryo development may be enhanced by priming treatments, although the sensitivity varies with regard to concentration, treatment time, chemical material type, and plant species. However, in this study, pretreat- 
ments with $\mathrm{KNO}_{3}$ at different concentrations did not affect the cumulative germination of G. triflora var. japonica (Figure 7). Further studies using other priming materials and combinations of GAs are required to enhance the germination and uniformity of G. triflora var. japonica seeds and establish a mass propagation program.

\section{Materials and Methods}

\subsection{Seed Preparation}

The mature seeds of G. triflora var. japonica were collected on 24 October 2020 from plants growing at Mt. Sobaeksan, Danyang, Korea. After the seeds were cleaned, they were examined to determine seed characteristics. The seed length, seed width, and weight of 1000 seeds were $0.95 \pm 0.04 \mathrm{~mm}, 0.38 \pm 0.01 \mathrm{~mm}$, and $0.0434 \pm 0.002 \mathrm{mg}$, respectively. After the seeds were dried for 1-2 weeks, they were sealed in a plastic bag stored at $4{ }^{\circ} \mathrm{C}$ until the beginning of the experiment on 11 March 2021.

\subsection{Water Imbibition Test}

The ability of the seeds to imbibe water under laboratory conditions (approximately $25 \pm 2{ }^{\circ} \mathrm{C}$, room humidity (RH) of $40 \%-50 \%$ ) was determined. Four replicates of 100 seeds were initially weighed using an electronic balance (ML204/01, Mettler Toledo, Columbus, $\mathrm{OH}, \mathrm{USA}$ ). Subsequently, the G. triflora var. japonica seeds from each replicate were individually placed on two layers of filter paper (Whatman No. 2, Toyo Roshi Kaisha, Ltd., Tokyo, Japan) moistened with distilled water in $90 \times 15 \mathrm{~mm}$ plastic Petri dishes (SPL Life Sciences Co., Ltd., Pocheon, Korea). The fresh weight of the G. triflora var. japonica seeds was measured after $3,6,9,12,24$, and $72 \mathrm{~h}$ of incubation, and the water uptake by seeds was calculated using the water uptake formula detailed by Baskin and Baskin [20]:

$$
\% W_{s}=\left[\left(W_{i}-W_{d} / W_{d}\right)\right] \times 100
$$

where $W_{s}$ is the increase in seed mass, $W_{i}$ is the seed mass after a given interval of imbibition, and $W_{d}$ is the initial seed mass at $0 \mathrm{~h}$.

\subsection{Seed Morphology and Embryo Growth}

To identify MD dormancy, G. triflora var. japonica seeds were incubated at $25^{\circ} \mathrm{C}$, and then the measurement of seed morphology was carried out from 11 March to 24 May 2021. Ten seeds were cut along the major or minor axis using a razor blade (stainless blade, Dorco, Seoul, Korea), and then the cross-section was measured under a digital microscope (DVM6, Leica Microsystems GmbH, Wetzlar, Germany). The increase in embryo length was measured at dispersal and just before germination. The ratio of embryo length to seed length (E:S ratio) was calculated using the formula detailed by Vandelook et al. [36].

$$
\text { E:S ratio = seed length/embryo length }
$$

\subsection{Temperature Regime Treatments}

To identify the optimal temperature for germination, the seeds were incubated at 5,15 , $20,25,15 / 6$, and $25 / 15^{\circ} \mathrm{C}$ with a photoperiod of $12 / 12 \mathrm{~h}$ (light/dark) in a growth chamber (TGC-130H, Espec Mic Corp., Aichi, Japan). Light intensity during the daytime across all temperature regimes was $40 \pm 10 \mu \mathrm{mol} \cdot \mathrm{m}^{-2} \cdot \mathrm{s}^{-1}$ photosynthetic photon flux density (PPFD) using fluorescent lamps. Four replicates of 25 seeds were placed separately on a $1 \%$ agar (Agar, Sigma-Aldrich, St. Louis, MO, USA) medium in $60 \times 15 \mathrm{~mm}$ plastic Petri dishes (SPL Life Sciences Co., Ltd., Pocheon, Korea), which were sealed with a parafilm (PM-996, Bemis Company Inc., Neenah, WI, USA) during incubation.

\subsection{Cold Stratification Period}

To investigate the response to cold stratification for germination, the seeds were incubated for $0,4,8$, or 12 weeks at $5{ }^{\circ} \mathrm{C}$. After each cold stratification period, the seeds were transferred to a growth chamber $\left(25^{\circ} \mathrm{C}\right.$ with a photoperiod of $12 / 12 \mathrm{~h}$ (light/dark)). Light 
intensity during the daytime across all the temperature regimes was $40 \pm 10 \mu \mathrm{mol} \cdot \mathrm{m}^{-2} \cdot \mathrm{s}^{-1}$ PPFD using fluorescent lamps. Four replicates of 25 seeds were each placed separately on a $1 \%$ agar medium in $60 \times 15 \mathrm{~mm}$ plastic Petri dishes, which were sealed with a parafilm during incubation.

\subsection{Promoting Germination with $\mathrm{GA}_{3}$ and $\mathrm{KNO}_{3}$}

Four different concentrations of a GA 3 ( $\geq 90 \%$, Sigma-Aldrich, St. Louis, MO, USA) solution ( 0 (control), 10,100 , or $\left.1000 \mathrm{mg} \cdot \mathrm{L}^{-1}\right)$ and of a potassium nitrate $\left(\mathrm{KNO}_{3}, 99.0 \%\right.$; Daejung Chemical Co., Ltd., Siheung, Korea) solution (0 (control), 1000, 2000, or $4000 \mathrm{mg} \cdot \mathrm{L}^{-1}$ ) were applied to promote germination. The seeds were soaked in the various solutions for $24 \mathrm{~h}$ under laboratory conditions (approximately $25 \pm 2{ }^{\circ} \mathrm{C}$, RH of $40 \%-50 \%$ ). The control groups were soaked in distilled water for $24 \mathrm{~h}$. After the pretreatment with $\mathrm{GA}_{3}$ and $\mathrm{KNO}_{3}$, the seeds were washed five times with distilled water, and germination characteristics were observed at $25^{\circ} \mathrm{C}$ in a growth chamber (12/12 h light/dark photoperiod with fluorescent lamps at $\left.40 \pm 10 \mu \mathrm{mol} \cdot \mathrm{m}^{-2} \cdot \mathrm{s}^{-1} \mathrm{PPFD}\right)$. Four replicates of 25 seeds were each placed separately on a $1 \%$ agar medium in $60 \times 15 \mathrm{~mm}$ plastic Petri dishes, which were sealed with a parafilm during incubation.

To evaluate the $\mathrm{GA}_{3}$ pretreatment, the seed germination stage, germination (G), MGT, and GE of the G. triflora var. japonica seeds were calculated as follows [42,54]:

$$
\begin{gathered}
\% \mathrm{G}=\mathrm{G}_{30} / \mathrm{N} \times 100 \\
\mathrm{MGT}(\text { days })=\sum(\mathrm{T} \times \mathrm{S}) / \sum \mathrm{S} \\
\% \mathrm{GE}=\mathrm{G}_{7} / \mathrm{N} \times 100
\end{gathered}
$$

where $\mathrm{N}$ is the total number of seeds, $\mathrm{T}$ is the time in days from day 1 to the final day of the germination test, and $S$ is the total number of germinated seeds on day $T . G_{7}$ and $G_{30}$ are the total numbers of seeds germinated on days 7 and 30, respectively, after sowing.

\subsection{Data Collection and Statistical Analysis}

The number of germinated seeds was counted for 2-3 days. Each seed was considered to have germinated when the radicle emergence reached at least $2 \mathrm{~mm}$. Statistical analyses were performed using the statistical analysis system (SAS 9.4, SAS Institute Inc., Cary, NC, USA). The differences between the E:S ratios of seeds at dispersal and immediately before germination were assessed using paired $t$-tests. The germination experiment results were subjected to analysis of variance and Tukey's multiple range tests $(p \leq 0.05)$. Regression and graphing were performed using SigmaPlot 12.0 (Systat Software Inc., San Jose, CA, USA).

\section{Conclusions}

This study concluded that the G. triflora var. japonica seeds had intact seed coats that were permeable to water absorption and did not exhibit PY dormancy. In addition, the seeds were detached in an immature embryo state and showed MD dormancy that required embryo growth until just before germination, similar to the Gentianaceae family $[16,18]$. Furthermore, in the temperature treatments, the cumulative germination did not reach even $15.0 \%$ within 30 days; therefore, the seeds were judged to have MPD dormancy. However, no seeds were affected by osmotic priming ( $\mathrm{KNO}_{3}$ treatment). In conclusion, G. triflora var. japonica seeds have a non-deep simple MPD, which can be released by cold stratification and pretreatment with $\mathrm{GA}_{3}$ to completely break dormancy and enhance germination. Considering the decrease in MGT and dormancy breaking of G. triflora var. japonica seeds, pretreatment with $100 \mathrm{mg} \cdot \mathrm{L}^{-1} \mathrm{GA}_{3}$ is an effective method of releasing dormancy. In addition, cold stratification for 4-8 weeks could serve as an alternative to $\mathrm{GA}_{3}$ for seed germination. This knowledge aids in clarifying the ecophysiological mechanisms under different environmental conditions and in developing useful methods for obtaining G. triflora var. japonica seedlings in a mass propagation setting. 
Author Contributions: Conceptualization, H.-M.K. and C.-S.N.; methodology, H.-M.K.; formal analysis, H.-M.K.; investigation, H.-M.K., J.-H.K., D.-H.L., Y.-H.J., C.-Y.P., M.-H.L. and K.-M.K.; resources, J.-H.L.; data curation, H.-M.K.; writing-original draft preparation, H.-M.K.; writingreview and editing, H.-M.K.; project administration, C.-S.N.; funding acquisition, C.-S.N. All authors have read and agreed to the published version of the manuscript.

Funding: This research was funded by the R\&D Program for Forest Science Technology (project No. 2021400B10-2125-CA02) provided by the Korea Forest Service (Korea Forestry Promotion Institute).

Institutional Review Board Statement: Not applicable.

Informed Consent Statement: Not applicable.

Data Availability Statement: Not applicable.

Acknowledgments: We thank the Korea National Park for assistance with seed collections and observations.

Conflicts of Interest: The authors declare no conflict of interest.

\section{References}

1. Fenner, M.; Thompson, K. The Ecology of Seeds; Cambridge University Press: Cambridge, UK, 2005.

2. Chen, S.; Chien, C.; Chung, J.; Yang, Y.; Kuo, S. Dormancy-break and germination in seeds of Prunus campanulata (Rosaceae): Role of covering layers and changes in concentration of abscisic acid and gibberellins. Seed Sci. Res. 2007, 17, 21-32. [CrossRef]

3. Baskin, C.C.; Baskin, J.M. Seeds: Ecology, Biogeography, and Evolution of Dormancy and Germination, 2nd ed.; Academic Press: San Diego, CA, USA, 2014.

4. Zhang, K.; Zhang, Y.; Walck, J.L.; Tao, J. Non-deep simple morphophysiological dormancy in seeds of Angelica keiskei (Apiaceae). Sci. Hortic. 2019, 255, 202-208. [CrossRef]

5. Chahtane, H.; Kim, W.; Lopez-Molina, L. Primary seed dormancy: A temporally multilayered riddle waiting to be unlocked. J. Exp. Bot. 2017, 68, 857-869. [CrossRef] [PubMed]

6. Lee, S.Y.; Rhie, Y.H.; Kim, K.S. Non-deep simple morphophysiological dormancy in seeds of Thalictrum rochebrunianum, an endemic perennial herb in the Korean Peninsula. Hortic. Environ. Biotechnol. 2015, 56, 366-375. [CrossRef]

7. Née, G.; Xiang, Y.; Soppe, W.J. The release of dormancy, a wake-up call for seeds to germinate. Curr. Opin. Plant Biol. 2017, 35, 8-14. [CrossRef] [PubMed]

8. Owolabi, O.J.; Omogbai, E.K.I.; Obasuyi, O. Antifungal and antibacterial activities of the ethanolic and aqueous extract of Kigeli africana (Bignoniaceae) stem bark. Afr. J. Biotechnol. 2007, 6, 1677-1680.

9. Ebrahimi, R.; Hassandokht, M.; Zamani, Z.; Kashi, A.; Roldan-Ruiz, I.; Bockstaele, E. Seed morphogenesis and effect of pretreatments on seed germination of Persian shallot (Allium hirtifolium Boiss.), an endangered medicinal plant. Hortic. Environ. Biotechnol. 2014, 55, 19-26. [CrossRef]

10. Saha, S.; Monroe, A.; Day, M.R. Growth, yield, plant quality and nutrition of basil (Ocimum basilicum L.) under soilless agricultural systems. Ann. Agric. Sci. 2016, 61, 181-186. [CrossRef]

11. Park, S.Y.; Kim, J.Y.; Oh, M.M. Determination of adequate substrate water content for mass production of a high value-added medicinal plant, Crepidiastrum denticulatum (Houtt.) Pak \& Kawano. Agronomy 2020, 10, 388.

12. Lee, H.R.; Kim, H.M.; Jeong, H.W.; Hwang, S.J. Growth and bioactive compounds of Salvia plebeian R. Br. grown under various ratios of red and blue light. Horticulturae. 2020, 6, 35. [CrossRef]

13. Kim, Y.J.; Kim, H.M.; Kim, H.M.; Lee, H.R.; Jeong, B.R.; Lee, H.J.; Kim, H.J.; Hwang, S.J. Growth and phytochemicals of ice plant (Mesembryanthemum crystallinum L.) as affected by various combined ratios of red and blue LEDs in a closed-type plant production system. J. Appl. Res. Med. Aromat. Plants 2021, 20, 100267.

14. Kim, H.J.; Na, H.Y. Seed dormancy and germination in Oenanthe stolonifera as affected by temperature and gibberellic acid. Hortic. Environ. Biotechnol. 2021, 62, 1-8. [CrossRef]

15. Baskin, C.C.; Baskin, J.M. Germination ecology of seeds with morphophysiological dormancy. In Seeds: Ecology, Biogeography, and Evolution of Dormancy and Germination; Baskin, C.C., Baskin, J.M., Eds.; Academic Press: San Diego, CA, USA, 1998 ; pp. 87-100.

16. Finch-Savage, W.E.; Leubner-Metzger, G. Seed dormancy and the control of germination. New Phytol. 2006, 171, 501-523. [CrossRef]

17. Pérez-García, F.; Varela, F.; González-Benito, M.E. Morphological and germination response variability in seeds of wild yellow gentian (Gentiana lutea L.) accessions from northwest Spain. Botany 2012, 90, 731-742. [CrossRef]

18. Cuena-Lombrña, A.; Porceddu, M.; Dettori, C.A.; Bacchetta, G. Discovering the type of seed dormancy and temperature requirements for seed germination of Gentiana lutea L. subsp. lutea (Gentianaceae). J. Plant Ecol. 2017, 11, 308-316. [CrossRef]

19. Schwienbacher, E.; Navarro-Cano, J.A.; Neuner, G.; Erschbamer, B. Seed dormancy in alpine species. Flora-Morphol. Distrib. Funct. Ecol. Plants 2011, 206, 845-856. [CrossRef]

20. Baskin, J.M.; Baskin, C.C. A classification system of seed dormancy. Seed Sci. Res. 2004, 14, 1-16. [CrossRef] 
21. Mattana, E.; Pritchard, H.W.; Porceddu, M.; Stuppy, W.; Bacchetta, G. Interchangeable effects of gibberellic acid and temperature on embryo growth, seed germination and epicotyl emergence in Ribes multiflorum ssp. Sandalioticum (Grossulariaceae). Plant Biol. 2012, 14, 77-87.

22. Cuena-Lombraña, A.; Porceddu, M.; Dettori, C.A.; Bacchetta, G. Gentiana lutea L. subsp. lutea seed germination: Natural versus controlled conditions. Botany 2016, 94, 653-659. [CrossRef]

23. Kwon, H.J.; Shin, S.L.; Kim, Y.R.; Kim, S.Y. Effects of temperature, gibberellic acid, and $\mathrm{KNO}_{3}$ treatments on seed germination of the wild plant Maesa japonica. Seed Sci. Res. 2020, 48, 65-72. [CrossRef]

24. Shu, K.; Liu, X.; Xie, Q.; He, Z. Two faces of one seed: Hormonal regulation of dormancy and germination. Mol. Plant 2016, 9 , 34-45. [CrossRef] [PubMed]

25. Park, H.B.; Ko, C.H.; Lee, S.Y.; Kim, S.Y.; Yang, J.C.; Lee, K.C. Ecophysiology of seed dormancy and germination in four Lonicera (Caprifoliaceae) species native to Korea. J. Ecol. Environ. 2019, 43, 25. [CrossRef]

26. Rhie, Y.H.; Lee, S.Y. Seed dormancy and germination of Epimedium koreanum Nakai. Sci. Hortic. 2020, 272, 109600. [CrossRef]

27. Davitashvili, N.; Karrer, G. Taxonomic importance of seed morphology in Gentiana (Gentianaceae). Bot. J. Linnean Soc. 2010, 162, 101-115. [CrossRef]

28. Korea National Arboretum. Nature. Available online: http:/ /www.nature.go.kr (accessed on 31 May 2021).

29. Paik, W.K.; Chung, Y.J. A taxonomic study of the Gentiana (Gentianaceae) in Korea. Korean J. Plant Res. 2006, 19, 8-14.

30. Whang, M.S.; Park, J.H. Pharmacognostical studies on the Chinese crude drug "Yong Dam". Korean J. Pharmacogn. 2001, 32, 1-5.

31. Kim, Y.G.; Kim, H.S. Effects of Gentiana scabra Bunge var. buergeri Max. extract on blood glucose and lipid composition in streptozotocin induced hyperglycemic rats. Korean J. Life Sci. 1998, 8, 381-386.

32. Matsukawa, K.; Ogata, M.; Hikage, T.; Minami, H.; Shimotal, Y.; Saitoh, Y.; Yamashita, T.; Ouchi, A.; Tsutsumi, R.; Fujioka, T.; et al. Antiproliferative activity of root extract from Gentian plant (Gentiana triflora) on cultured and implanted tumor cells. Biosci. Biotechnol. Biochem. 2006, 70, 1046-1048. [CrossRef] [PubMed]

33. Yeom, M.S.; Nguyen, T.K.; Cho, J.S.; Oh, M.M. Improving germination rate of Coastal Glehnia by cold stratification and pericarp removal. Agronomy 2021, 11, 944. [CrossRef]

34. De Souza, T.V.; Voltolini, C.H.; Santos, M.; Paulilo, M.T.S. Water absorption and dormancy-breaking requirements of physically dormant seeds of Schizolobium parahyba (Fabaceae-Caesalpinioideae). Seed Sci. Res. 2012, 22, 169-176. [CrossRef]

35. Baskin, C.C.; Baskin, J.M. When breaking seed dormancy is a problem. Native Plants J. 2003, 4, 17-21. [CrossRef]

36. Vandelook, F.; Bolle, N.; Van Assche, J.A. Seed dormancy and germination of the European Chaerophyllum temulum (Apiaceae), a member of a trans-atlantic genus. Ann. Bot. 2007, 100, 233-239. [CrossRef] [PubMed]

37. Baskin, C.C.; Baskin, J.M. A revision of Martin's seed classification system, with particular reference to his dwarf-seed type. Seed Sci. Res. 2007, 17, 11-20. [CrossRef]

38. Walck, J.F.; Baskin, C.C.; Baskin, J.M. Seeds of Thalictrum mirabile (Ranunculaceae) require cold stratification for loss of nondeep simple morphophysiological dormancy. Can. J. Bot. 1999, 77, 1769-1776. [CrossRef]

39. Hartmann, H.T.; Kester, D.E.; Davies, F.T.; Geneve, R.L. Plant. Propagation: Principles and Practices, 6th ed.; Prentice Hall: Upper Saddle River, NJ, USA, 1997; pp. 157-158.

40. Walck, J.L.; Hidayati, S.N.; Okagami, N. Seed germination ecophysiology of the Asian species Osmorhiza aristata (Apiaceae): Comparison with its North American congeners and implications for evolution of types of dormancy. Am. J. Bot. 2002, 89, 829-835. [CrossRef] [PubMed]

41. Yamauchi, Y.; Ogawa, M.; Kuwahara, A.; Hanada, A.; Kamiya, Y.; Yamaguchi, S. Activation of gibberellin biosynthesis and response pathways by low temperature during imbibition of Arabidopsis thaliana seeds. Plant Cell 2004, 16, 367-378. [CrossRef]

42. Simpson, M.J.A.; Webb, C.J. Germination in some New Zealand species of Gentiana: A preliminary report. N. Z. J. Bot. 1980, 18, 495-501. [CrossRef]

43. González-López, Ó.; Casquero, P.A. Effects of $\mathrm{GA}_{3}$ pregerminative treatment on Gentiana lutea L. var. aurantiaca germination and seedlings morphology. Sci. World J. 2014, 2014, 751279. [CrossRef]

44. Millaku, F.; Gashi, B.; Abdullai, K.; Aliu, S.; Mirsade, O.; Krasniqu, E.; Mata, V.; Rysha, A. Effects of cold-stratification, gibberellic acid and potassium nitrate on seed germination of yellow gentian (Gentiana lutea L.). Afr. J. Biotechnol. 2012, 11, 13173-13178. [CrossRef]

45. Toh, S.; Imamura, A.; Watanabe, A.; Nakabayashi, K.; Okamoto, M.; Jikumaru, Y.; Hanada, A.; Aso, Y.; Ishiyama, K.; Tamura, N.; et al. High temperature-induced abscisic acid biosynthesis and its role in the inhibition of gibberellin action in Arabidopsis seeds. Plant Physiol. 2008, 146, 1368-1385. [CrossRef]

46. Cho, J.S.; Jang, B.K.; Lee, C.H. Seed dormancy and germination characteristics of the endangered species Cicuta virosa L. in South Korea. Hortic. Environ. Biotechnol. 2018, 59, 473-481. [CrossRef]

47. Huarte, H.R.; Benech-Arnold, R.L. Hormonal nature of seed responses to fluctuating temperatures in Cynara cardunculus (L.). Seed Sci. Res. 2010, 20, 39-45. [CrossRef]

48. Née, G.; Kramer, K.; Nakabayashi, K.; Yuan, B.; Xiang, Y.; Miatton, E.; Finkemeier, I.; Soppe, W.J.J. DELAY OF GERMINATION1 requires PP2C phosphatases of the ABA signaling pathway to control seed dormancy. Nat. Commun. 2017, 8, 72. [CrossRef] [PubMed]

49. Paparella, S.; Araújo, S.S.; Rossi, G.; Wijayasinghe, M.; Carbonera, D.; Balestrazzi, A. Seed priming: State of the art and new perspectives. Plant Cell Rep. 2015, 34, 1281-1293. [CrossRef] [PubMed] 
50. Lara, T.S.; Lira, J.M.S.; Rodrigues, A.C.; Rakocevic, M.; Alvarenga, A.A. Potassium nitrate priming affects the activity of nitrate reductase and antioxidant enzymes in tomato germination. J. Agri. Sci. 2014, 6, 72-80. [CrossRef]

51. Hamidi, R.; Pirasteh-Anosheh, H. Comparison effect of different seed priming methods on sunflower germination and seedling growth. Intl. J. Agron. Plant Prod. 2013, 4, 1247-1250.

52. Duermeyer, L.; Khodapanahi, E.; Yan, D.; Krapp, A.; Rothstein, S.J.; Nambara, E. Regulation of seed dormancy and germination by nitrate. Seed Sci. Res. 2018, 28, 150-157. [CrossRef]

53. Cho, J.S.; Jeong, J.H.; Lee, C.H. The effects of environmental conditions and chemical treatments on seed germination in Astilboides tabularis (Hemsl.) Engl. Korean J. Hortic. Sci. Technol. 2016, 34, 363-371.

54. Ellis, R.H.; Roberts, E.H. Improved equations for the prediction of seed longevity. Ann. Bot. 1980, 45, 13-30. [CrossRef] 